Egypt. J. Aquat. Biol. \& Fish., Vol. 9, No. 1:81-96(2005) ISSN 1110-6131

\title{
BIOCHEMICAL AND HISTOPATHOLOGICAL STUDIES ON THE MUSCLES OF THE NILE TILAPIA (OREOCHROMIS NILOTICUS) IN EGYPT
}

\author{
Sabry S. El-Serafy ${ }^{\prime}$; Seham A. Ibrahim ' and Soaad A. \\ Mahmoud $^{2}$ \\ 1-Department of Zoology, Faculty of Science, Zagazig University, \\ Benha Branch \\ 2-National Institute of Oceanography and Fisheries, Fish Research \\ station, Cairo, Egypt
}

Key words: River Nile, tilapia. heavy metals, biochemical analysis, histopathology.

\begin{abstract}
Q icchemical contents in the muscle of Oreochromis niloticus were determined in fish specimens collected from El-Kanater, Benha, Zefta and Talkha stations. Analysis revealed that the water content in muscles was higher in immature than mature fish. The maximum values of protein content in fish flesh were recorded during spring at Benha and Zefta stations. Seasonal variations in the amount of protein. fat. carbohydrate water and ash were observed. The fat in fish muscles was fairly high in winter and early spring in adult specimens, i.e.. during the pre-spawning months, then it dropped after the breeding season. A direct relationship between fat and protein was found. The muscle carbohydrate was correlated to feeding and spawning activity. High energy values were found throughout the prespawning period.

Heavy metals concentrations were detected in the muscles of O.niloticus and found to follow the order: $\mathrm{Fe}>\mathrm{Pb}>\mathrm{Cu}>\mathrm{Zn}$.

The histopathological study of fish muscles showed marked signs of haemorrhage and hemolysis.
\end{abstract}

\section{INTRODUCTION}

In Egypt several studies have been reported on the biochemical constituents of the Egyptian fishes among them. El-Saby (1934) determined the dietetic value of some Egyptian food fishes and Latif \& Fouda (1976) reported the biochemical constituents of most Red sea fishes ín Egypt. Similarly. Shakweer et al. (1998) mentioned 
that. the major biochemical constituents of the muscles of Mugil cephalus namely protein, lipid, ash and water contents differed significantly from one fishing area to another.

On the other hand. Saleh ef al. (1988) studied the heavy metals concentration in whole body. tissues and organs of Tilapia sillii in Wady El-Rayan, Egypt. They reported that the heavy metals concentration in fish did not change significantly with the season of collection or with the age of the fish, except for lead. Abdel-Baky et al. (1998) studied the heavy metals concentrations in some organs of Oreochromis aureus in Lake Manzalah, Egypt. They reported that, the concentrations of the tested metals ( $\mathrm{Cd}$.. Cu., $\mathrm{Zn}$ and $\mathrm{Pb}$ ). in different organs and tissues of Oreochromis aureus varied considerably with regards to seasons and sites.

The effect of a sublethal concentration $\left(6.8 \mathrm{mgL}^{-1}\right)$ of cadmium chloride on the digestive system of the teleost fish Heieropneusier fossilis after exposure for 30 days was examined by Sasstry and Gupta (1978). Lamas et al. (1995) cited that the turbot (Scopthalmis maimis/) infected by a viral erythrocytic. showed hemorrhages in the head. mouth. fins. exophthalmia and abdominal distension. Degeneration of muscle fibers was accompanied by an intense inflammatory edema.

The present study aimed to investigate the biochemical composition of fish flesh and histopathological changes in muscles of Oreochromis niloticus caught from different localities of the

Damietta Nile Branch.

\section{MATERIALS AND METHODS}

\section{Biochemical analysis:}

Fresh samples of $O$. niloticus were collected seasonally during the year 1997 from El-Kanater. Benha. Zefta and Talkha selected stations. Fishes were dissected out. their skin was carefully removed and a flesh sample of about $10 \mathrm{gm}$ was taken from the mid-dorsal region. cut into small pieces and weighed. The muscle samples of each sex were analyzed separately. in order to assess any possible differences in the scasonal cycle of the fish. Moisture content of the samples was determined by drying the flesh in an oven at $100^{\circ} \mathrm{C}$ to constant weight. Fat was estimated by extraction of dried nuscle samples using ether solvent for about $12 \mathrm{~h}$. in a Soxhlet apparatus. 
Protein was determined by micro-kjeldal nitrogen estimation method according to El-Aggan (1982).

\section{Heavy metals analysis:}

Fish samples were analysed for heavy metals according to Dalziel and Baker (1983). where specimens of muscles were weighed, dried in an oven at $105^{\circ} \mathrm{C}$. for 48 hrs in silica beakur digested by concentrated nitric acid. diluted to $25 \mathrm{ml}$ by distilled water. The results were expressed as $\mathrm{Mg} / \mathrm{gm}$ wet weight of the tissue.

Levels of metals in samples were measured by Atomic Absorption spectrophotometry (Hitachi Japan) with detection limit $\left.1 \mathrm{mgL}^{-1}\right)$. Results were expressed in part per million (ppm) of the dry weight of the flesh.

\section{Histological examination:}

The specimens were carefully dissected; pieces of the muscles were fixed in Bouin fluid. After fixation. the specimens were delhydrated, then muscles were cleared by methyl benzoate. After clearing the process of embedding was performed. After embedding the specimens were supported by paraffin as a block and then transversely cut at a thickness of 4-6 $\mu$.

\section{RESULTS \\ 1. Biochemical composition of fish flesh}

Variations in the four major biochemical constituents of fish flesh of Oreochramis niloticus namely moisture, protein. lipids and ash contents, in addition to the carbohydrates during different seasons are presented in Figure 1.

Seasonal variation in water and lipids content:

For the biochemical analysis specimens inclusion the juvenile specimens. male and female fishes were analysed and the results are presented in Figure 1. Water being the most important constituent. contributing maximum value to the chemical composition in fish tissues and showed high degree of variation. 
The amount of fat in the flesh of O.niloticus varied from one season to another. The percentage of fat contents in both males and females are presented in Figure 1.

It has to be mentioned that the water content in the flesh of both fish sexes underwent a wide range of variation but was inversely related with the fat content, i.e., as the fat was increased the water content decreased and vice verse.

\section{Seasonal variation in protein content:}

Figure (1) shows the protein cycle in muscles of both sexes at different stations. It can be observed that the protein ranged from $73.1 \%$ to $85.6 \%, 73.0 \%$ to $87.5 \%, 73.5 \%$ to $88.0 \%$ and $73.8 \%$ to $85.2 \%$ for the fish samples caught from El-Kanater. Benha. Zefta and Talkha stations. respectively. The protein content in fish flesh had its lowest percentage $(73.0 \%)$ in the adult female sample from Benha during autumn. however the highest percentage $(88.0 \%)$ was found in fish sample collected from Zefta station (fingerlings) during spring season.

\section{Ash content:}

The ash content showed jts lowest value $(3.7 \%)$ in fish flesh sample (fingerlings) from Talkha station during summer season (Figure 1). However. its highest value $(10.9 \%)$ was found in adult fish flesh sample from El-Kanater station during autumn season.

\section{Carbohydrate content:}

Carbohydrate was estimated by calculation (difference). It is obvious from the data obtained that. the values of carbohydrate were relatively higher during winter and spring seasons than during summer and autumn (Figure 1).

\section{Heary metals in fish flesh}

The concentration of four selected heavy metals (Iron. Zinc. Copper and Lead) in the flesh of Oreochromis niloricus caught during 1997 from the selected different localities at Nile Damietta branch are presented in Table (1). It showed that the highest average value of iron concentration was recorded from fish caught from El-Kanater station ( $320 \mu \mathrm{g} / \mathrm{g}$.) during summer but the lowest value was recorded at Zefta station $(75 \mu \mathrm{g} / \mathrm{g}$.) in autunn season. However. 
iron concentration showed the highest value along the year round (290. 293.320 and $240 \mu \mathrm{g} / g$ ) for winter. spring. summer and autumn seasons. respectively.

Zinc concentrations in the fish muscles had been flictuated from 15.2-45.6 $\mu \mathrm{g}$. A maximum value was observed for fish caught from Benha station during spring though high values were recorded in summer for those caught from all the studied stations. $\mathrm{Zn}$ concentrations obtained from all fish examined in autumn were much lower than those obtained during other seasons (25.7. 22.0. 19.5 and $15.2 \mu \mathrm{g} / \mathrm{g}$ ) for samples taken from El-Kanater. Benha. Zefta and Talkha stations. respectively.

Concerning $\mathrm{Cu}$ concentration in fish. it had reached its maximum value at Talkha station $(9.6 \mu \mathrm{g} / \mathrm{g})$ and falled to its minimum value at Benha station $(0.98 \mu \mathrm{g} / \mathrm{g})$. The results also showed that higher values of $\mathrm{Cu}$ was recorded (9.6. 7.4. 4.5 and 3.8 $\mu \mathrm{g} / \mathrm{g}$ ) during summer. spring. winter and.autumn respectively but the lowest values were obtained during winter $(1.9,1.2,1.3$ and 4.5 $\mu \mathrm{g} / \mathrm{g})$ at El-Kanater, Benha, Zefta and Talkha stations. respectively.

The maximum concentration of lead $(11.67 \mu \mathrm{g} / \mathrm{g})$ was recorded in fish caught from El-Kanater station during spring. however. high values of lead $(9.40,5.95,5.80$ and $8.50 \mu \mathrm{g} / \mathrm{g})$ were recorded during winter at El-Kanater. Benha, Zefta and Talkha stations respectively.

\section{Histopathological changes in the muscles:}

The normal skeletal muscles are composed chiefly of segmental myomeres. Each myomere is regarded as apparent muscle and its fibers are parallel to the long axis of the body (Figure 2).

However. the fish caught from the selected stations on the River Nile show that the hypoderm layer between dermis and muscle showed necrosis in connective tissue with hemorrhages and hemocidrine (Figure 3).

The muscle sections showed degeneration and necrosis of muscle fibers and intrafibrilar edema (Figure $4 a \& 4 b$ ) with thickness and dilation in blood vessel (Figures $5 \mathrm{a} \& 5 \mathrm{~b}$ ). Dermal 
layer showed degeneration of the collagen bundles that were loose in some regions and collapsed in others (Figure 6).

\section{DISCUSSION}

A knowledge of the biochemical composition of fish flesh is of paramount importance to-evaluate its nutritive value. Also the biochemical composition specially water and lipids as well as fish protein, contents are important for fish meal or other fishery products.

Water as an important constituent, contributes highly to the chemical composition in fish tissues and may show high degree of variation (Bruce, 1924).

The obtained data for the analyzed specimens showed that. the mean percentages of water, protein, lipid, ash and carbohydrate are $80.95 \%, 10.45 \%, 6.75 \%$ and $1.41 \%$ respectively. These results are in agreement with those reported by Hammadi ef al. (1974). Fouda ef al. (1986) and Wassef \& Shehata (1991) who showed that water content seems to be the principal constituent, protein comes next. followed by lipids. ash and carbohydrate.

The higher values of water content during summer and autumn seasons may be related to the spawning period as reported by Abdel Fattah (1979) who gave an explanation for that as to be due to endocrine source.

Lipid content variation was obvious as it is greatly affected by the principal factors such as the stage of sexual development and feeding conditions (Wassef, 1978. Khalil et al. 1986. Wassef \& Shehata. 1991). These variations may also declare the effect of the annual reproductive cycle on muscle composition.

Figure (1) shows the protein cycle in muscles of both sexes. Similar to fat. protein values are inversely proportional to water suggesting that depletion in water content is due to the increase in fat and protein levels.

As in most cxamined fish. with the exception of those caught from Talkha station. protein and ash contents were proved to he more or less stable components. In contrast. lipid content undergoes wide seasonal variations. particularly for adults. These results are in agreement with that reported by Love. (1970) who mentioned that lipid is the most variable component in fish. From the present results 
water. lipid and ash contents were found to be higher during autumn and summer than during winter and spring, however, protein content showed a limited variation. It is difficult distinguishing between the effect of many factors which play a part in lipid fluctuation, but the principal ones are the stage of sexual development and feeding conditions (Wasset and Shehata. 1991). These variations may also reveal the effect of the annual reproductive cycle on muscles composition.

The concentrations of heavy metals (iron, zinc, copper and lead) in flesh of Oreochromis niloticus seasonally caught from Damietta branch are presented in Table (1). The studied areas are known to receive the wastes of agricultural, industrial and domestic effluents from different sources. The present data for $\mathrm{Zn}$. $\mathrm{Cu}$ and $\mathrm{Pb}$ studied in fish caught from different stations were found to be less than these reported by WHO (1977) and Hamed (1998).

Abdel-Nasser el al. (1996) found that the highest average concentration of $\mathrm{Pb}$ and $\mathrm{Cu}$ in muscle of Oreochromis niloticus caught from Assiut Governorate were $1.78 \mathrm{ppm}$ and $15.93 \mathrm{ppm}$ respectively. The level of $\mathrm{Pb}$ was lesser than the permissible limit (2.62 ppm), however $\mathrm{Cu}$ level was higher than that limit (10 ppm). Also Abdel Baky et al. (1998) found that muscle tissue of $O$. cinretus tends to retain lower concentrations of trace metals $(\mathrm{Cu} 1.5 \mu \mathrm{g} / \mathrm{g} . \mathrm{Zn}$ $28.52 \mu \mathrm{g} / \mathrm{g}$ and $\mathrm{Pb} 0.31 \mu \mathrm{g} / \mathrm{g}$ ). They also reported that heavy metals concentrations in fish muscle increase with the increase in amounts of drainage and sewage effluents.

The histopathological changes in epidermis, dermis. hypodermis and underlying muscles observed in the present study showed necrosis of epithelial and mucous cells of the epidermis. degeneration, necrosis and edema of muscle fibers. They also revealed congestion and dilation of the dermal blood vessels together with hypodermic inflammatory signs which may extend to the underlying muscle. These results are in accordance with these obtained by Roberts (1972), Easa (1974), Oyuind (1985); Timar and Timar (1986) and Yacoub (1999). 


\section{REFERENCES}

Abdel-Baky. T.E.; Hagras. A.E.; Hassan. S.H. and Zyadah. M.A.. (1998). Heavy metals concentration in some organs of Oreochromis (Tilapia aureus) Stein in lake Manzalah. Egypt. J. Egypt, Ger. Soc. Zool.. 25 (A) Comparative Physiology: 237-256.

Abdel-Fattah, M.E., (1979). Seasonal biochemical changes in Pylanyx spp. from Egyptian Mediterranean water of Alexandria M.Sc. thesis Fac. Sci. Alex. Univ. Egypt.

Abd-Nasser. M.; Shaaban, A. A.; Aly, S.M. and Sayed, M. M. (1996). Levels of some heavy metals in fish caught from River Nile at Assiut Governorate, Egypt. Assiut Vet. Med. J. 37: p.68.

Bruce. J.R. (1924). Changes in the chemical composition of the tissues of the herring in rclation to age and maturity. Biochem. J. 18: 469-485.

Dalziel. J. and Baker, C. (1983). Analytical methods for measuring metals by Atomic Absorption Spectrophotometry. FAO Fish Technical 212: 14-21.

Easa, M., (1974). Histopathological studies of lesions in the skin of mirror carp (C.yprinus carpio L.) M.V.Sc. Thesis. Fac. Vet. Med. Cairo Univ.

El-Aggan. W. H., (1982). A comparative study of the growth and nitrogenous activity of five Azolla species. Ph.D. Thesis Cairo Univ. Egypt.

Ej-Saby. M.K. (1934). Dietetic value of certain Egyptian food fishesRappet Pro.. 8: 127-143.

Fouda. Y.H.; Abu Salem. F.M.: El-Dashlouty. S.: Rasmy. N.M. and Sorore. A.. (1986). Chemical constituents of Bolti fish. Annals. Agric. Sci. Fac. Ain Shams Univ. Cairo Egypt. 3/(1): 499-518.

Groman. D. B. (1982). Histology of the striped bass. American Fisheries Soc. Monograph. 3: P116.

Hamed. M. A.. (1998). Distribution of trace metals in the Rjver Nile ecosystem Damietta branch between Mansoura City and Damietta province. J. Egypt Ger. Soc. Zool. Vol. 27 (A) comparative Physiology. 399-415. 
Hammadi, K.A., Youssef, M.K.E. and Bassiouny, S.S. (1974). Evaluation of nutritive value of eleven local Nile fish varieties. Abstracts of the first Egyptian conference for food science and technology, Paper, 25:32-33.

Khall, M.S.; Hilmy, A.; Badawi, H. and Wassef, F. (1986). Proximate composition of wild and reared gilthead bream Chrsophys auratus (Forster), Bull. Fac. Sci. Cairo Univ.. 5: $1-30$.

Lamas, J; Noya. M; Figucras, A. and Toranzo, A.E. (1995). pathology associated with a viral erythrocytic infection in turbot, Scophtholmus maximus (L.) J. Fish Dis.. 18.

Latif, A.F.A and Fouda, A.M.A. (1976). Proximate composition of some Red Sea Fishes. Bull. Inst. Oceanog \& Fish. Egypt. 6: $55-81$.

Love, R.M. (1970). The chemical biology of fishes. London: Academic press.

Oyuind. S. (1985). Kidney histological of atlantic salmon (Salmo zalar) suffering from cold water vibriosis or hitra-Disease. Bull. Eur. Ass. Fish Pathol. 5(4): p.88

Roberts. R.J. (1972). Histopathological changes in liver and brain of fish exposed to endosulfan insecticide during TSR fly control operations in Botswana. J. Fish Dis., 5: 53-159.

Saleh, S. A. L.E.; Saleh, M.A.: Fouda, M.M.; Saleh. M.A.. Abdel Latif, M.S. and Wison. B.L. (1988). Inorganic pollution of the Man-Made lake of Wadi El-Raiyan in Egyptian desert. Arch. Environ. Cotam. Toxocol.. 17: 391-403.

Sasstry. K.V. and Gupta, P.K. (1978). Histopathological and enzymological studies on the effect of chronic lead nitrate intoxication in the digestive system of a fresh water teleost. Chamna punctatus. Environ. Res.. 17.

Shakweer. L.M.: El-Ebiary. E.H. and Zaki. M.A. (1998). Comparative study on the major biochemical constituents in the muscles of Mugil cephalus inhabiting the Mediterranean water. the Northern Delta lakes and fish farms of Egypt. Bull. Nat. Inst. Of Oceanogr. \& Fish Egy'pt. 24: 79-101.

Timar. G. and Timar. M. (1986). Haemornhagic septicaenia with high mortality in pikoperch. (Stizosiedion lucioperla. 1-1758) in lake Egridiss. Turkey. Vet. Fakult. Derg. Isi Ankara Univ. esi.. $32(1): 33-41$. 
Wassef E. and shehata. W. B. (1991). Biochemical composition of Gilthead Bream Spartus currata from lake Bardawil (Egypt). J. K. A. L. Mar. Sci.. ?: 111-122.

Wassef. F... (1978): Biological and physiological studies on marine and acclimatized tish Spartus atrata L. Ph. D. Thesis. Fac. Sci. Cairo. L niv. P2?5.

WHO (1977). Environmental health Criteria. Lead World Health Organization Report. Genevap.. 18-51.

Yacoub. A. M. (1999). Effect of pollution in different localities of River Nile on ('larias lazera Ph. D. Thesis. Fac. Sci. Ain Shams Unis. 


\begin{tabular}{|c|c|c|c|c|c|c|}
\hline & 40 & . & $\therefore$ & $\stackrel{n}{\sim}$ & $\vec{\sim}$ & $\stackrel{\text { in }}{r}$ \\
\hline & $\begin{array}{c}0 \\
0 \\
\Xi\end{array}$ & 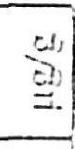 & $\vec{m}$ & $\begin{array}{l}\infty \\
0 \\
0\end{array}$ & $\Xi$ & $\stackrel{\infty}{m}$ \\
\hline & 年 & 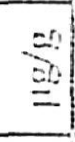 & $\stackrel{\sim}{\sim}$ & $\underset{N}{N}$ & $\stackrel{\sim}{\sim}$ & $\stackrel{v}{v}$ \\
\hline & 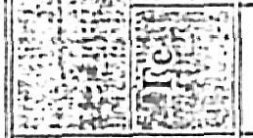 & $\frac{\infty}{\infty}$ & $\stackrel{\circ}{\sim}$ & $\approx$ & $\approx$ & $\stackrel{\infty}{0}$ \\
\hline & 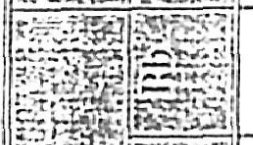 & $\begin{array}{l}0 \\
0 \\
=0\end{array}$ & $\begin{array}{l}\vec{v} \\
\dot{v}\end{array}$ & $?$ & $\underset{m}{\dot{m}}$ & $?$ \\
\hline & 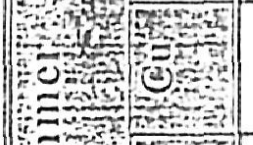 & $\begin{array}{l}\infty \\
\partial \\
=\end{array}$ & $\stackrel{0}{\circ}$ & $\hat{\sim}$ & $\stackrel{\varrho}{\check{2}}$ & $\stackrel{0}{\circ}$ \\
\hline & 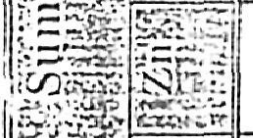 & $\begin{array}{l}\infty \\
\vdots \\
\Xi\end{array}$ & $\stackrel{\sim}{n}$ & $\vec{\infty}$ & $\stackrel{m}{m}$ & $\stackrel{\sim}{\sim}$ \\
\hline$\stackrel{\check{\Sigma}}{\hat{\Sigma}}$ & 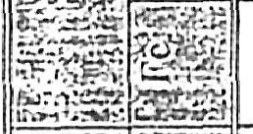 & 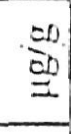 & $\underset{\sim}{\stackrel{\sim}{\sim}}$ & $\Xi$ & $\tilde{\theta}$ & 욤 \\
\hline 豆 & 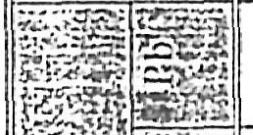 & $\stackrel{\infty}{D}$ & $\Xi$ & 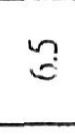 & $\stackrel{0}{\longrightarrow}$ & $\Xi$ \\
\hline 总 & 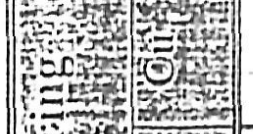 & $\begin{array}{l}00 \\
=0\end{array}$ & $\stackrel{\infty}{m}$ & $n$ & $\overrightarrow{\sim i}$ & $\stackrel{\nabla}{\sim}$ \\
\hline $\begin{array}{l}\bar{\Xi} \\
\bar{E}\end{array}$ & 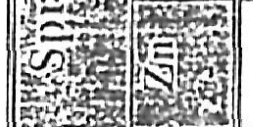 & 焉 & 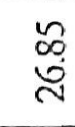 & $\begin{array}{l}\stackrel{\leftrightarrow}{\sigma} \\
\forall\end{array}$ & $\stackrel{?}{\mathrm{~g}}$ & $\frac{\vec{N}}{\tilde{N}}$ \\
\hline 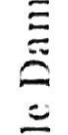 & 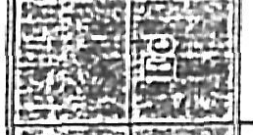 & $\stackrel{\Delta D}{D}$ & 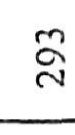 & $\stackrel{\infty}{0}$ & $\approx$ & $\stackrel{?}{\stackrel{N}{N}}$ \\
\hline $\bar{z}$ & 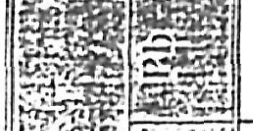 & $\stackrel{\infty}{0}$ & $\vec{\sigma}$ & $\begin{array}{l}\approx \\
\sim \\
\sim\end{array}$ & $\begin{array}{l}\infty \\
\dot{v}\end{array}$ & $\infty$ \\
\hline $\begin{array}{l}\bar{\equiv} \\
\bar{\equiv}\end{array}$ & Fo & $=0$ & $\approx$ & $\because$ & $?$ & $\frac{6}{\square}$ \\
\hline $\begin{array}{l}\bar{\Xi} \\
\vdots\end{array}$ & $\begin{array}{ll}2 & 0 \\
2 & 0\end{array}$ & $\begin{array}{l}\because \\
\equiv\end{array}$ & $\overline{\bar{c}}$ & $\stackrel{\overrightarrow{\dot{d}}}{\mathrm{~d}}$ & $\frac{v}{N}$ & $\stackrel{r}{2}$ \\
\hline 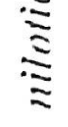 & 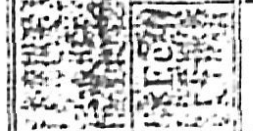 & $\begin{array}{l}\because \because \\
\because \\
\because\end{array}$ & $\stackrel{尺}{\precsim}$ & 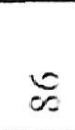 & $\infty$ & $\stackrel{ }{2}$ \\
\hline & 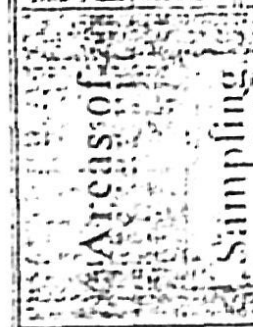 & & 急 & 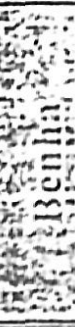 & 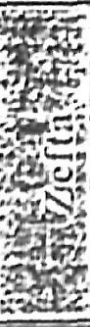 & 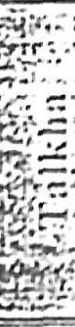 \\
\hline
\end{tabular}




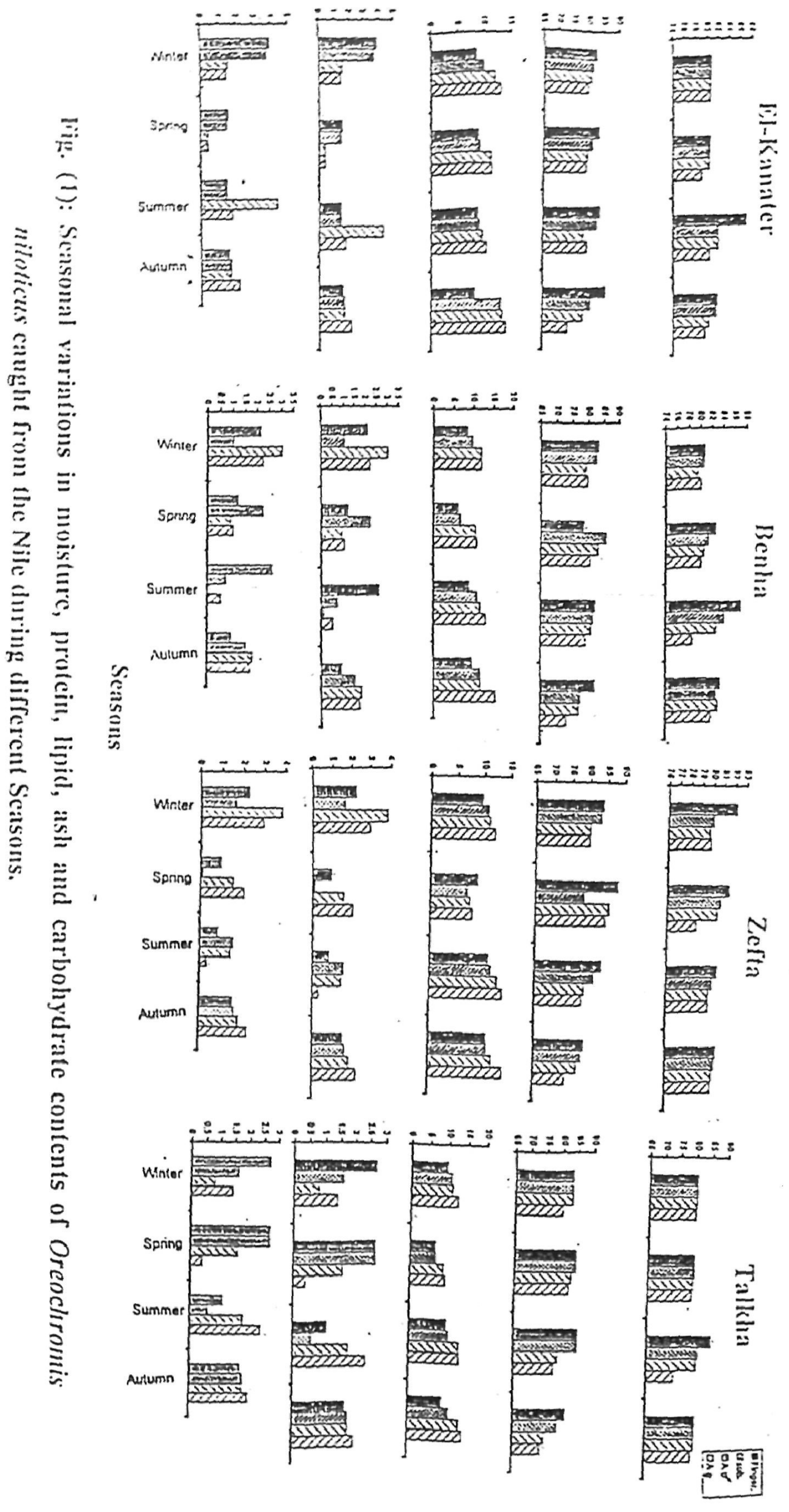




\section{Explanation of Figures}

Figure (2) : L.S of nomal muscle of Oreochromis niloticus showing the myomers (M) (Bouin`s H\& E) $\times 400$.

Figure (3): L.S of muscle of ()reochromis niloticus collected from El-Kanater showing: -

1- Necrosis area in hypoderm.

2- Hemorrhage. hemoly'sis and hemocidrin.

3- Severe degeneration and necrosies in muscle fibers (Bouin`s H\&E) x 400.

Figure (4a \& 4b): L.S of muscle of oreochromis niloticus collected from talkha showing:-

4- Severe destruction in muscle fibers.

5- Intrafibrillar edema. (Bouin`s H \& E) x 400.

Figure (5a \& 5b): L.S of muscle of Oreochromis niloticus collected from Benha showing:-

6- Epidermal cells are missing.

7- Thickness and dilation in blood vessel.

8- Hemolysis and hemocidrin around blood vessel.

9- Severe destruction in muscle fibers (Bouin`s $\mathrm{H} \&$ E)x400

Figure (6): L.S of muscle of ()reochromis niloticus collected from Zefta showing:-

10- Necrosis in hypodermis layer.

11-Severe degeneration in muscle fibers. 

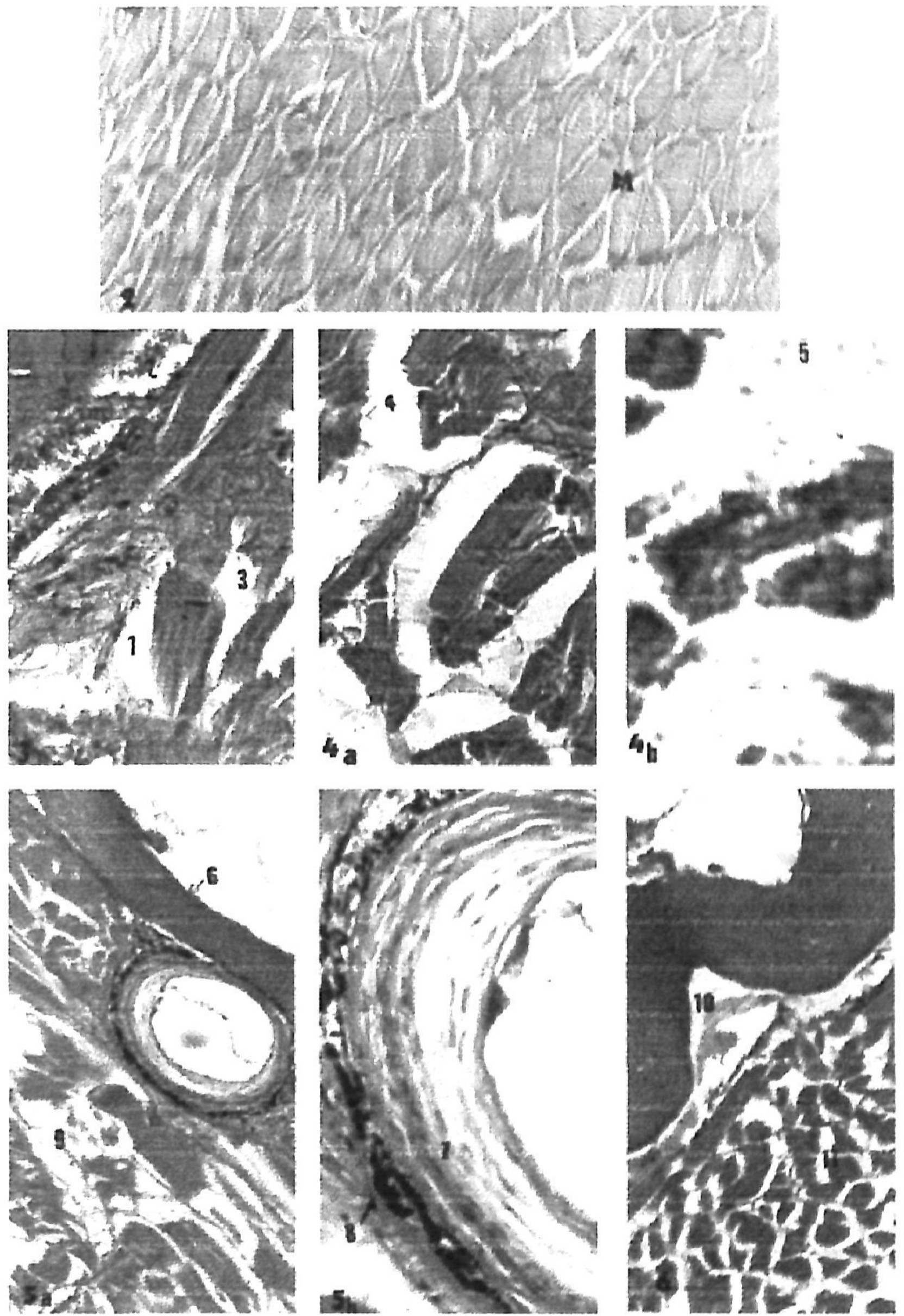